\title{
Can barley (Hordeum vulgare L. s.I.) adapt to fast climate changes? A controlled selection experiment
}

Alemayehu, Fikadu Reta; Frenck, Georg; van der Linden, Leon; Mikkelsen, Teis Nørgaard; Bagger Jørgensen, Rikke

\section{Published in:}

Genetic Resources and Crop Evolution

Link to article, DOI:

$10.1007 / \mathrm{s} 10722-013-0021-1$

Publication date:

2013

Link back to DTU Orbit

Citation (APA):

Alemayehu, F. R., Frenck, G., van der Linden, L., Mikkelsen, T. N., \& Bagger Jørgensen, R. (2013). Can barley (Hordeum vulgare L. S.I.) adapt to fast climate changes? A controlled selection experiment. Genetic Resources and Crop Evolution, 61, 151-161. https://doi.org/10.1007/s10722-013-0021-1

\section{General rights}

Copyright and moral rights for the publications made accessible in the public portal are retained by the authors and/or other copyright owners and it is a condition of accessing publications that users recognise and abide by the legal requirements associated with these rights.

- Users may download and print one copy of any publication from the public portal for the purpose of private study or research.

- You may not further distribute the material or use it for any profit-making activity or commercial gain

- You may freely distribute the URL identifying the publication in the public portal 


\title{
Can barley (Hordeum vulgare L. s.l.) adapt to fast climate changes? A controlled selection experiment
}

\author{
Fikadu Reta Alemayehu • Georg Frenck • \\ Leon van der Linden • Teis Nørgaard Mikkelsen • \\ Rikke Bagger Jørgensen
}

Received: 22 February 2013/ Accepted: 1 July 2013/Published online: 7 August 2013

(C) Springer Science+Business Media Dordrecht 2013

\begin{abstract}
The projected future climate will affect the global agricultural production negatively, however, to keep abreast of the expected increase in global population, the agricultural production must increase. Therefore, to safeguard the future crop yield and quality, the adaptive potential of crops to environmental change needs to be explored in order to select the most productive genotypes. Presently, it is unknown whether cereal crops like spring barley can adapt to climate stressors over relatively few generations. To evaluate if strong selection pressures could change the performance of barley to environmental stress, we conducted a selection experiment over five plant generations $(\mathrm{G} 0-\mathrm{G} 4)$ in three scenarios, where atmospheric $\left[\mathrm{CO}_{2}\right]$ and temperature were increased as single factors and in combination. The treatments represented the expected environmental characteristics in Northern Europe around year $2075[700$ ppm
\end{abstract}

F. R. Alemayehu - T. N. Mikkelsen .

R. B. Jørgensen $(\bowtie)$

Department of Chemical and Biochemical Engineering,

DTU, Ris $\emptyset$ Campus, BIO-309, Frederiksborgvej 399,

4000 Roskilde, Denmark

e-mail: rijq@kt.dtu.dk

G. Frenck

Department of Animal and Plant Sciences,

The Osborne Lab, University of Sheffield, Western Bank, Sheffield S10 2TN, UK

L. van der Linden

Australian Water Quality Centre, Adelaide, SA, Australia
$\mathrm{CO}_{2}, 22 / 17{ }^{\circ} \mathrm{C}$ (day/night)] as well as a control mimicking present day conditions (390 ppm $\mathrm{CO}_{2}$, $19 / 12{ }^{\circ} \mathrm{C}$ ). Two different barley accessions, a modern cultivar and an old landrace, were evaluated in terms of yield and biomass production. In all treatments representing future environmental scenarios, the G4-generation of selected plants did not improve its reproductive output compared to the G0-generation, as G4 produced less seeds and had a lower yield than unselected plants. These results indicate that barley might not respond positively to rapid and strong selection by elevated $\left[\mathrm{CO}_{2}\right]$ and temperature, contrary to previous results from oilseed rape. The two barley accessions analyzed presented almost the same response pattern in a given treatment, though the modern cultivar had the highest yield in the climate scenarios, while the landrace was superior in yield under present day climate conditions.

Keywords Barley genotypes - Breeding Generational selection - Genetic adaptation . Hordeum vulgare L. s.l.

\section{Introduction}

Crop yields are predicted to decrease under increased climatic stress (Taub et al. 2000), why the adaptive capacity of crop genotypes needs to be explored to select suitable lines for breeding towards stress tolerance. The use of environmentally tailored genotypes is 
one of the measures that can be applied to secure a primary production providing for a growing world population with minimum costs to the environment (Araus et al. 2008). The globe is facing an increase in temperature, elevated atmospheric carbon dioxide and other greenhouse gases (Taub et al. 2000; Prasad et al. 2002; IPCC 2007). If radical decreases in greenhouse gasses are not achieved, the global mean temperature may incase about $4.0{ }^{\circ} \mathrm{C}$ [degrees Celsius; likely range: $2.4-6.4{ }^{\circ} \mathrm{C}$ (IPCC 2007)] within this century. More recent projections assume an even larger increase in average global temperature of up to $5{ }^{\circ} \mathrm{C}$ (http:// climateprediction.net/). Increased temperatures and heat stress are primarily linked with high evapotranspiration, acceleration of plant development and consequently shortening of developmental phases, leading to an early maturation and decreased yields (Altenbach et al. 2003; Barnabas et al. 2008; Elke et al. 2011). The negative effects of higher temperatures might partially be compensated by elevated carbon dioxide concentrations. Elevated $\left[\mathrm{CO}_{2}\right]$ (square brackets are used to designate concentrations of chemical substances) has often been reported to promote crop yields and overall performance through increased photosynthesis (Long et al. 2006a, b; Makino 2011) and improved plantwater relations (Warren et al. 2011). At the end of this century the atmospheric $\left[\mathrm{CO}_{2}\right]$ is expected to increase to nearly $700 \mathrm{ppm}$ (IPCC 2007) from its current level of about $394 \mathrm{ppm}$. Although elevated $\left[\mathrm{CO}_{2}\right]$ may affect crop production positively, its combination with other environmental factors may well result in lower plant productivity. The evidence is limited, but Tubiello et al. (2000), Prasad et al. (2002) and Frenck et al. (2011) documented that the increase in yield as a result of elevated $\left[\mathrm{CO}_{2}\right]$ may be counteracted and even more so, when combined with higher temperature.

Variation in environmental stress tolerance between and within landraces and cultivars is little explored (Luo et al. 2009; Ceccarelli et al. 2010; Anderson et al. 2011), and therefore, targeted breeding efforts should involve screening of existing accessions. High genetic diversity may enhance the environmental adaptation potential of a cultivar (Hakala et al. 2012), however, it is often anticipated that the recurrent breeding leading to modern crops have reduced their genetic variation and thus their adaptability. In barley - the crop under study here-the genetic variation has been analyzed e.g. by Kraakman et al. (2004) and Brantestam et al. (2007) using AFLP and SSR markers, respectively. They found marker variation that could easily differentiate between spring cultivars. In the SSR analysis of 22 loci, Brantestam et al. (2007) did not detect a decrease in genetic variation between old accessions (e.g. landraces) and modern cultivars. To what extent the apparent genetic variation in barley will translate into tolerance to the prevailing abiotic stress under climate change is yet unexplored. If not present in the present crop cultivars, this highly requested environmental tolerance might be found in the landraces or cross compatible wild relatives (Ellis et al. 2000; Newton et al. 2010). In a long term monitoring program Nevo et al. (2012) for example found that natural climate stress created profound adaptive changes in wild barley (Hordeum spontaneum K. Koch).

Barley (Hordeum vulgare L. s.l.) is one of the most widely cultivated cereals worldwide ranking fourth after wheat, maize and rice (USDA 2011). Barley plays a huge role in the economy as it is essential for global production of animal fodder, beer and whisky. The present study represents one of few studies in plants, where the adaptive potential to the future climate stressors is analyzed in a manipulative experiment; such studies have not previously been reported for barley. In this experiment we exposed two different barley accessions, a landrace and a modern cultivar, to a selection pressure over several generations in climate scenarios representing the climate in Northern Europe around 2075 (IPCC 2007, scenario A1FI).

\section{Materials and methods}

\section{Experimental conditions}

In future climate scenarios mimicked (Table 1 for details) within the climate phytotron Ris $\varnothing$ Environmental Risk Assessment Facility (RERAF), two spring barley accessions, a modern cultivar 'Anakin', and an old landrace "Gammel Dansk" were analyzed. Each of the two barley accessions was represented by the first (G0-generation) and the fourth (G4-generation), from a preceding selection performed under the same climate scenarios as the present comparison (for details see Frenck et al. 2011): Each of four identical chambers in the phytotron accounted for a specific climate scenario. A chamber had the dimension in meters $4.0 \mathrm{~m} \times 6.0 \mathrm{~m} \times 3.1 \mathrm{~m}(\mathrm{w} \times 1 \times \mathrm{h})$ and was 
equipped with an individual control of light level, temperature, humidity, $\mathrm{CO}_{2}$ and ozone concentration. The gas concentrations were verified by sequential gas sampling from all chambers connected to one set of analyzers. Twenty eight high pressure mercury and 14 halogen lamps $(1,000$ and $400 \mathrm{~W}$, respectively) per chamber generated a 16/8 h day/night light regime. Daily simulation of sunrise and sunset was performed within the first and last hour of the day period by gradually changing light intensity. During day time, photosynthetic photon flux density (PPFD) averaged $520 \mu \mathrm{mol}$ photons $\mathrm{m}^{-2} \mathrm{~s}^{-1}$ at the height of mature crop canopy. All climate scenarios were provided with the same amount of water: At the beginning of the day, plants were watered by an automatic irrigation system providing $4.4 \mathrm{~L} \mathrm{~m}^{-2} \mathrm{day}^{-1}$ to the plants. This is more than average for Danish summer precipitation, but extra water was given to compensate for higher losses from the pot soil relative to natural conditions, e.g. due to the pot-constrain of the root distribution and the loss of excess water due to pot drainage. The amount of water delivered was decreased at the beginning of leaf senescence (approximately within the third month after sowing) in a stepwise fashion to promote maturation and seed ripening. A relative humidity of $55 / 70 \%$ (day/night) was established for all treatments. To ensure complete air mixing, two tube enclosed fans $(\varnothing 0.45 \mathrm{~m}$, outlet wind speed average was $5 \mathrm{~m} \mathrm{~s}^{-1}$ ) in every chamber circulated air day and night.
The conditions in control and manipulated treatments are summarized in Table 1. The control treatment was designed to simulate present Nordic/Danish early summer climate. In all treatments a low background ozone concentration of approximately $30 \mathrm{ppb}$ was added continuously to mimic the natural tropospheric ozone outside the phytotron. Plants were cultivated in $11 \mathrm{~L}$ polypropylene pots each filled with $4 \mathrm{~kg}$ of a standard soil (Pindstrup substrate No. 6, Pindstrup Mosebrug A/S, Denmark), and each pot was supplemented with $10 \mathrm{~g}$ of NPK fertilizer 21-3-1 (Kemira, Denmark A/S). As 8 barley plants were evenly distributed per pot, a competition regime for below ground resources including water was created. In every climate treatment, 48 plants per genotype (6 pots with 8 plants each) and generation founded experimental core population. The different plant populations ('Anakin' and "Gammel Dansk", with generations G0 and G4) were spatially separated on individual moveable tables. Plant density was 130 individuals $/ \mathrm{m}^{2}$. Plants of each population were restricted from growing over the table margins by lightweight fencing. To avoid chamber specific biases and minimize confounding effects of micro-environmental variations, the tables with the plants and their corresponding treatment were relocated among the chambers of the phytotron every week, at which time the relative position of a given population within a chamber was also changed. This weekly rotation was accomplished within $1 \mathrm{~h}$, the time period necessary for

Table 1 Summary of manipulated environmental conditions for the four treatments in the present study

\begin{tabular}{|c|c|c|c|c|c|c|}
\hline & $\begin{array}{l}\mathrm{CO}_{2} \\
(\mathrm{ppm})\end{array}$ & $\begin{array}{l}\mathrm{CO}_{2} \text { std } \\
( \pm \mathrm{ppm})\end{array}$ & $\begin{array}{l}\text { Temperature } \\
\left({ }^{\circ} \mathrm{C}\right)\end{array}$ & $\begin{array}{l}\text { Temperature } \\
\text { std }\left( \pm^{\circ} \mathrm{C}\right)\end{array}$ & $\mathrm{RH}(\%)$ & $\mathrm{RH} \% \operatorname{std}( \pm \%)$ \\
\hline \multicolumn{7}{|c|}{ Day treatment } \\
\hline Ambient & 405.5 & 37.2 & 17.8 & 1.8 & 57.9 & 4.1 \\
\hline $\mathrm{CO}_{2}$ & 655.9 & 30.6 & 18.3 & 2.1 & 57.9 & 4.1 \\
\hline $\mathrm{CO}_{2} \mathrm{~T}$ & 684.2 & 31.7 & 22.3 & 1.9 & 58.0 & 4.2 \\
\hline Temp & 398.9 & 21.1 & 22.4 & 2.2 & 58.0 & 4.2 \\
\hline \multicolumn{7}{|c|}{ Night treatment } \\
\hline Ambient & 430.2 & 20.6 & 15.3 & 1.7 & 64.8 & 4.4 \\
\hline $\mathrm{CO}_{2}$ & 622.5 & 20.7 & 15.0 & 1.6 & 64.8 & 4.4 \\
\hline $\mathrm{CO}_{2} \mathrm{~T}$ & 677.9 & 19 & 18.2 & 1.9 & 64.9 & 4.5 \\
\hline Temp & 410.9 & 15 & 17.8 & 1.4 & 64.9 & 4.4 \\
\hline
\end{tabular}

The $\mathrm{CO}_{2}$ concentration intended was $390 \mathrm{ppm}$ (ambient) or $700 \mathrm{ppm}$ (elevated), and the temperature was set to $12 / 17^{\circ} \mathrm{C}$ night/day (ambient) and $17 / 22{ }^{\circ} \mathrm{C}$ (elevated). All treatments had a background ozone concentration of $30 \mathrm{ppb}$ (intended; realized $23-34 \pm 3.8-7.1 \mathrm{ppb})$ 
the new environmental conditions of experimental treatment to equilibrate within a chamber.

\section{Plant material}

The Danish spring barley 'Anakin', is a modern cultivar released in 2006 by Nordic Seed A/S (http://www. nordicseed.dk/; Denmark) and "Gammel Dansk" is a landrace cultivated around 1850; "Gammel Dansk" is stored and propagated by NordGen (The Nordic gene bank; http://www.nordgen.org/; Sweden). Both accessions are two-rowed (i.e. only the central spikelet is fertile). 'Anakin' has a medium height and some tendency to lodging, while "Gammel Dansk" has long straws and therefore also lodges very easily. To confirm the inherent levels of genetic variation present in the accessions investigated, they were screened by AFLP according to Johannessen et al. (2002) using one primer combination for the specific amplification (EcoRI + AGC/ MseI + CGA) before the start of the selection experiment. Both accessions presented polymorphic markers; 12 of 62 , and 30 of 64 markers, were polymorphic in 'Anakin' and “Gammel Dansk", respectively. The production of the material for the present experiment was generated in a pre-study: The first experimental generation of plants, G1, was cultivated to maturity under selective conditions from seeds of G0 [G0 = "Anakin' (certified seed from the breeder) and "Gammel Dansk" (gene bank accession)]. Generation G2 was based on seeds chosen randomly from the pooled seed stock of G1 - and so on for the subsequent generations. Generations G1-G4 were all cultivated in the same selective scenario as the G0-generation, viz. one of the 4 treatments in Table 1 . All seeds were stored at $4{ }^{\circ} \mathrm{C}$ for the short periods before the next generation was sown.

During the final cycle of cultivation, the populations that were exposed to selection pressure under the future climate scenarios for five generations, G4plants, were cultivated simultaneously with unselected G0 plants from the original seed stock. For 'Anakin' and "Gammel Dansk" each of the two generations, G0 and G4, were divided into two batches, which were temporally delayed by 28 days in their cultivation (hereafter called groups).

\section{Harvests}

At maturity, the plants were harvested as pooled samples. The 8 plants per pot were harvested 4 by 4 , providing a total of 12 pooled samples per accession, generation and treatment $(2$ pools per pot $\times 6$ pots per treatment and accession). After drying, the seeds were separated from the vegetative biomass. Seed and shoot dry weight, seed number and thousand grain weight (TGW) were determined. Harvest index (HI) was calculated as the ratio of seed dry weight over shoot dry weight.

Data treatment and statistical analysis

In the analysis of experimental responses, shoot and aboveground dry weight and TGW data was $\log$ transformed, while values for seed dry weight, total seed number and HI were square-root transformed, to improve normality and homoscedasticity of the data sets. All statistical procedures were performed in $\mathrm{R}$ (version 2.11.1; R Development Core Team, 2010). Linear-mixed-effects models were fitted to each response parameter in two ways: (a) Modelling the effects of $\mathrm{CO}_{2}$, temperature, generation and their interactions, as represented in the experiment, as fixed effects and modelling the effects of genotypic origin as a random factor. (b) Integrating all individual and interactive effects of $\mathrm{CO}_{2}$, temperature, generation and genotype as fixed effects. For both procedures, all effects were nested within group and treatment, since the two temporal groups were assumed to be true replicates of the experiment. This procedure allowed the elucidation of directional responses common to the genotypes from the first statistical model structure, and the evaluation of the differences in the responses among the investigated genotypes, by the second. Subsequently, analysis of variance (ANOVA) was performed on the linear-mixed-effects models to reveal the effects of carbon dioxide, temperature, generation and their corresponding interactions on biomass responses to the applied treatments for the two genotypes. All effects resulting in a $p$ value $<0.05$ in the ANOVA were considered and reported as significant.

\section{Results}

Comparing yield and biomass of plants exposed to selection pressures and unselected

The production parameters for the G0- and G4generations are given in Figs. 1a-f and 2. There was no statistical support for generational differences 
between $\mathrm{G} 0$ and $\mathrm{G} 4$, even though the trend was that for reproductive parameters, generation $\mathrm{G} 4$ on the whole performed worse than G0 except in the ambient treatment. Highest yield and biomass were observed under the conditions with elevated $\mathrm{CO}_{2}$, while the temperature treatment had the lowest yield and seed number. Vegetative biomass seemed to be less affected by the elevated temperature than the reproductive traits. In the combined treatment with both elevated $\left[\mathrm{CO}_{2}\right]$ and temperature, the negative effect from the $+5{ }^{\circ} \mathrm{C}$ to seed number and yield per plant was not compensated for by the positive effects of elevated $\left[\mathrm{CO}_{2}\right]$.

Elevated $\left[\mathrm{CO}_{2}\right]$ had highly significant positive effects $(p<0.001)$ on all measures of plant production except for HI (Table 2). In contrast to the increase in production noted for elevated $\left[\mathrm{CO}_{2}\right]$, higher temperatures had significant negative impact $(p<0.001)$ on seed dry weight, seed number, aboveground dry weight and HI. The interactive effect of increased temperature and elevated $\left[\mathrm{CO}_{2}\right]$ was negative for all parameters, but was only significant for seed dry weight and aboveground dry weight $(p<0.01)$. There was no significant effect of generation (as a single factor) across all production parameters measured. An interactive effect of elevated $\mathrm{CO}_{2}$ and generation was detected for seed dry weight and aboveground dry weight $(p<0.05)$, in which the G4-generation was inferior to G0. The interactive effect of high temperature and generation was significant for seed dry weight, seed number and $\mathrm{HI}$; here again the G4-generation was less productive than G0. Significant positive interactions were found between $\mathrm{CO}_{2}$, temperature and generation for all production parameters except shoot dry weight and TGW (Table 2).
Fig. 1 a-f Production parameters for the two barley generations $\mathrm{G} 0$ (black columns) and G4 ( ray columns) in the four different treatments. a Average shoot dry weight per plant. b Average seed dry weight per plant. c Thousand grains weight. d Above ground dry weight per plant. e Total seed number per plant. f Harvest index (a) Average shoot dry weight per plant Shoot DW, g/plant

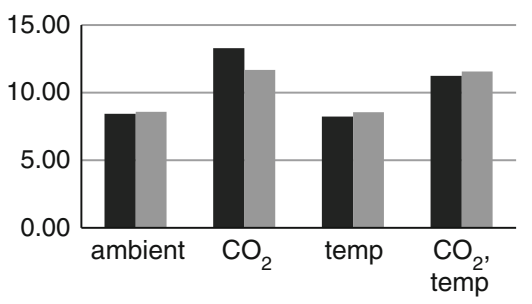

(c) Thousand grains weight

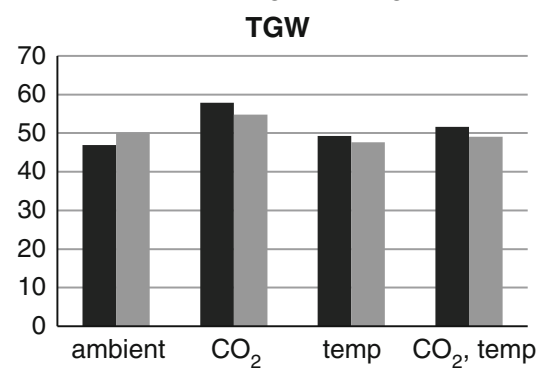

(e) Total seed number per plant Seeds, no/plant

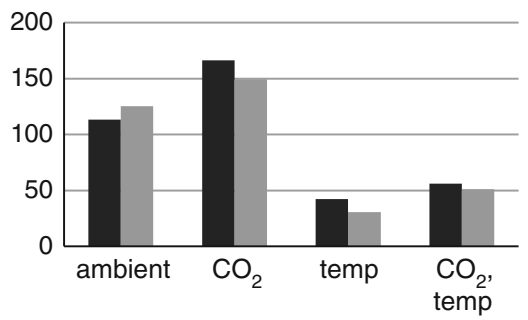

(b) Average seed dry weight per plant Seeds DW, g/plant

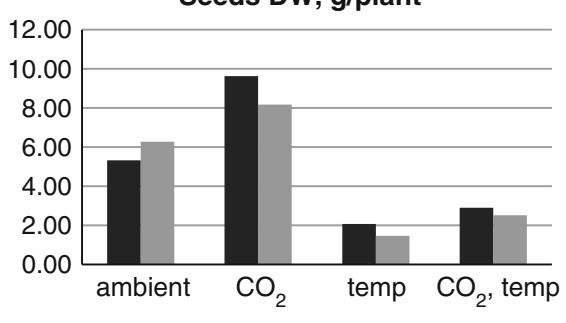

(d) Above ground dry weight per plant Above ground DW, g/plant

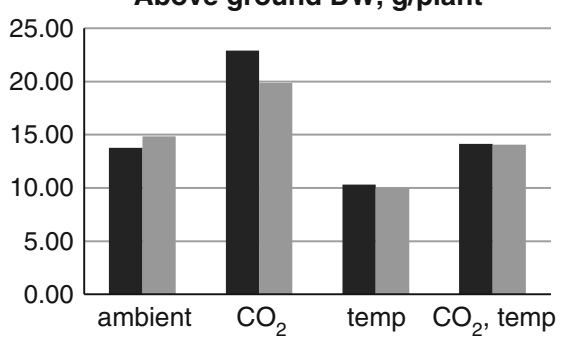

(f) Harvest Index

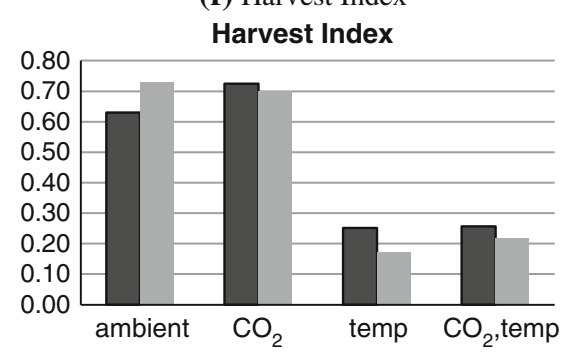




\section{Seed DW, g/plant}

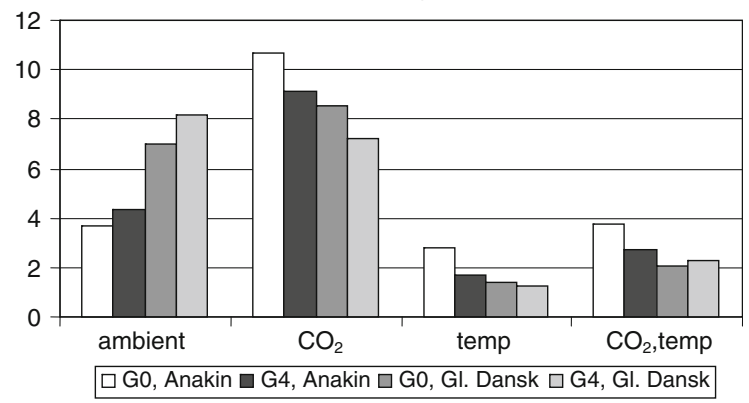

Fig. 2 Seeds dry weight (DW) for two barley cultivars, 'Anakin' and "Gammel Dansk", and two plant generations (G0 and G4) cultivated in different environments

\section{Discussion}

As a consequence of the projected increase in global population (UN 2010) and current trends in global average diet, total global food production will have to increase by $50-70 \%$ within the next 40 years to satisfy demand (Smil 2005; FAO 2009; Jaggard et al. 2010). To aggravate this pressure on primary production, the energy crisis raises the demand for crops to be used for bioenergy, e.g. it is expected that $14 \%$ of all cereals will be used for bioenergy by 2021 (OECD-FAO 2012). There is severe concern that primary production may not meet the food and energy demands of the future due to the increasing global temperature, increase in concentration of ozone in the troposphere and uncertainty about the amount and seasonality of precipitation (Jaggard et al. 2010; OECD-FAO 2012). OECD-FAO in their agricultural outlook 2012-2021 projects that for the next decade the growth in the global food production will decrease from presently $2.0-1.7 \%$ per year, and they emphasize the demand for increasing agricultural productivity. Among a number of measures for optimizing the future crop production is the development of cultivars adapted to the future climate stress. Such cultivars can best be bred if more knowledge is available on the effects from multifactorial climate changes and generational stress selection to different genotypes. The present experiment attempted to analyze the impacts of environmental stressors on the natural selection trajectory in barley.
Effects of elevated $\left[\mathrm{CO}_{2}\right]$ on the primary production

Our findings from the treatment applying elevated $\left[\mathrm{CO}_{2}\right]$ as a single factor seem to correspond well with other published data. For example, in a meta-analysis comprising 79 crop and wild species, Jablonski et al. (2002) documented an average increase in yield of $28 \%$ due to $\mathrm{CO}_{2}$ enrichment. The effects of elevated $\left[\mathrm{CO}_{2}\right]$ on wheat were reviewed by Long et al. (2006a), and they found that the average yield increase at $700 \mathrm{ppm}\left[\mathrm{CO}_{2}\right]$ could be predicted to be about 1.4 times that of ambient $\left[\mathrm{CO}_{2}\right]$, a result that is well in accordance with the present result from barley. In our treatment with $700 \mathrm{ppm}\left[\mathrm{CO}_{2}\right]$ the yield in barley increased by $54 \%$. There are only few other studies in barley on this topic; in one cultivar of winter barley, Manderscheid and Weigel (2006) evaluated effects of elevated $\left[\mathrm{CO}_{2}\right]$ using free air carbon dioxide enrichment (FACE) at $550 \mathrm{ppm}$, and they obtained yield increases of 7-15\%. For spring barley cultivated just one generation at $700 \mathrm{ppm}$ $\left[\mathrm{CO}_{2}\right]$, Clausen et al. (2011) observed, on average, a $57 \%$ increase in yield in four cultivars and three $F_{1}$ hybrids using the same climate phytotron (RERAF) as the present experiment. These authors allowed the plants unlimited access to water, while water availability under our experimental conditions was limited, as all future climate scenarios obtained the same amount as the ambient treatment. The yield increase at elevated $\left[\mathrm{CO}_{2}\right]$ was almost identical in these two phytotron experiments, possibly indicating that due to reduced stomatal conductance under elevated $\left[\mathrm{CO}_{2}\right]$, water was not the limiting factor. Both experiments sought to reproduce the nutrient availability found in a normal fertilized barley field, but the future cultivation of barley may not only be affected by the changed atmospheric composition and temperature, but low input conditions would also be a challenge to plant production. With a shortage of plant nutrients (e.g. phosphorus via rock phosphate supply limitation or nitrogenous fertilizer limitation via energy-economic pressures) and more stringent regulations on fertilizer applications, it is possible that the biomass gain under elevated $\left[\mathrm{CO}_{2}\right]$ will be limited by nutrient availability and allocation of extra biomass will primarily increase root biomass (MartínOlmedo et al. 2002). 
Table 2 Analysis of variance (ANOVA, response coefficients) result for a linear-mixed effects model integrating the independent and interactive effects of carbon dioxide $\left(\mathrm{CO}_{2}\right)$, temperature (temp) and generation (gen) on achieved shoot dry weight (Shoot DW), seeds dry weight (Seed DW), seed number (Seed No), above ground dry weight (Above DW), thousand grains weight (TGW) and harvest index (HI) for two spring barley cultivars each with two generations (G0 and G4)

\begin{tabular}{|c|c|c|c|c|c|c|}
\hline \multirow[t]{2}{*}{ Sources of variation } & \multicolumn{6}{|l|}{ Response } \\
\hline & Shoot DW & Seed DW & Seed No. & Above DW & TGW & HI \\
\hline $\mathrm{CO}_{2}$ & $4.8418 * * *$ & $0.6997 * * *$ & $0.0721 * * *$ & $8.2152 * * *$ & $6.2331 * * *$ & 0.0519 \\
\hline Temp & -0.1976 & $-0.9776 * * *$ & $-0.1356 * * *$ & $-4.3803 * * *$ & -2.4347 & $-0.3041 * * *$ \\
\hline Gen & 0.1507 & 0.1267 & 0.0154 & 0.6057 & 0.8325 & 0.0442 \\
\hline $\mathrm{CO}_{2}:$ temp & -1.8436 & $-0.4568 * *$ & -0.0434 & $-4.4013^{* *}$ & -3.8776 & -0.0459 \\
\hline $\mathrm{CO}_{2}$ :gen & -1.7517 & $-0.3878^{*}$ & -0.0395 & $-3.6589 *$ & -3.8828 & -0.0655 \\
\hline Temp:gen & 0.1671 & $-0.4303^{*}$ & $-0.0551 *$ & -1.0216 & -2.4051 & $-0.1619 * *$ \\
\hline $\mathrm{CO}_{2}$ :temp:gen & 1.7577 & $0.5796 *$ & 0.0699* & 4.0186* & 2.8949 & $0.1507 *$ \\
\hline
\end{tabular}

The presented coefficients were determined from the mixed effects model including cultivar as a random factor Significant effects indicated by bold and significant indices: $* p<0.05 ; * * p<0.01$; *** $p<0.001$

Effects of elevated temperature on the primary production

In the treatment with elevated temperature as a single factor, a reduction in average yield of $69 \%$ was observed. Clausen et al. (2011) recorded a reduction in yield of $27 \%$ from a similar temperature treatment with barley, but as mentioned above plants in their experiment experienced little or no water limitation. In line with that, negative effects of high temperature will get stronger under conditions of low rainfall or drought (IPCC 2007). While the effects from elevated $\left[\mathrm{CO}_{2}\right]$ seemed to affect generative and vegetative biomass almost equally, the effect of high temperature was more pronounced on generative traits like seed dry weight and seed number than on vegetative biomass. It seems likely that higher temperatures will lead to diminished efficiency in seed filling as increased temperatures and heat stress accelerate plant development and shorten developmental phases, resulting in early maturation and decrease in yield (Barnabas et al. 2008; Hatfield et al. 2011). Especially the plant's reproductive stage is sensitive to high temperature, and optimum temperature for yield is generally lower than optimum for vegetative growth (Hatfield et al. 2011). Hakala et al. (2012) in a study of Finnish barley cultivar trials from year 1976 to 2004 documented that when temperatures were high-more than $28{ }^{\circ} \mathrm{C}$ - over several days just before and after heading in barley, yield was substantially depressed. In our study we also observed substantial depression in yield under increased temperatures of $22 / 17{ }^{\circ} \mathrm{C}$ (day/night). Also a modeling study of wheat by Semenov and Shewry (2011) demonstrated that heat stress around flowering will be more detrimental to yield than drought later in the season, because cultivars will mature earlier.

Effects of the multifactor treatment with elevated $\left[\mathrm{CO}_{2}\right]$ and temperature on the primary production

As stated above, for elevated $\left[\mathrm{CO}_{2}\right]$ and temperature as single factors, our study showed effects to barley, which correspond with findings from other crop studies (e.g. Amthor 2001; Lobell and Field 2007; Barnabas et al. 2008). However, climatic factors will affect plants simultaneously making the outcome for production less predictable. Therefore, the multifactor combination of elevated $\left[\mathrm{CO}_{2}\right]$ and higher temperature was studied. The positive effect of elevated $\left[\mathrm{CO}_{2}\right]$ is clearly reduced, when combined with a temperature elevation of $5{ }^{\circ} \mathrm{C}$. Clausen et al. (2011) found a yield reduction in well watered barley of $14 \%$ from a multifactor treatment with the same levels of elevated $\left[\mathrm{CO}_{2}\right]$ and temperature, while we observed a $53 \%$ reduction in yield in the presumably water-limited multifactor treatment. In their review of potential future changes to arable crops, Jaggard et al. (2010) stated that elevated $\left[\mathrm{CO}_{2}\right]$ increases water use efficiency, and thereby the negative impacts of higher temperatures on crops would be approximately cancelled out. In agreement with this assumption our study documented that there was an improvement in yield compared to the treatment with only high 
temperature. Nevertheless, on average the magnitude of improvement was not able to compensate yield losses to the degree of ambient conditions productivity, indicating that the yield promoting effect of high $\left[\mathrm{CO}_{2}\right]$ is minor, when linked to temperature increases in this range. Consequently, the future elevated $\left[\mathrm{CO}_{2}\right]$ may not guarantee a sufficiently strong "fertilizing" effects on crop yield (Tubiello et al. 2000; Prasad et al. 2002; Frenck et al. 2011), depending of course on the crop, and the attained levels of $\left[\mathrm{CO}_{2}\right]$ and temperature increase. Tubiello et al. (2000) in a modeling study of Italian cropping systems under climate change, predicted that a mean annual temperature increase of $4{ }^{\circ} \mathrm{C}$ and $10 \%$ more annual precipitation combined with elevated $\left[\mathrm{CO}_{2}\right]$ at $700 \mathrm{ppm}$ will lead to reductions in barley yield by more than $20 \%$. These authors suggested that early sowing of spring crops is an option to minimize the impacts of high temperature; that however, demands selection of early types that can cope with low spring temperatures. For final shoot biomass and TGW we did not observe major effects from the different climate treatments, indicating that these production factors were less responsive to the environmental selection procedure applied here.

Accession specific responses to the future climate scenarios

The cultivar 'Anakin' produced $55 \mathrm{hkg} / \mathrm{ha}$ (hectokilograms per hectare) in the ambient treatment, and "Gammel Dansk" produced $97 \mathrm{hkg} / \mathrm{ha}$. The average yield of 'Anakin' in the field is about $65 \mathrm{hkg} / \mathrm{ha}$ (range 57.7-73.9 hkg/ha, the Nordic field trial system, data from 5 years; www.sortinfo.dk). As it is a landrace, "Gammel Dansk" has not been cultivated for many years; therefore yield data are not available. Based on the yield data for 'Anakin', the ambient conditions in the climate phytotron were almost as productive as field conditions. The plant density in this phytotron experiment and in the field- 130 contra 300 plants per $\mathrm{m}^{2}$ respectively - can likely explain the small divergence in yield (Scursoni and Satorre 2005). Despite the fact that "Gammel Dansk" performed significantly better than 'Anakin' under ambient condition, 'Anakin' showed its superiority under the future climate conditions. Differences in yield between old and new cultivars are the consequence of breeding; for example the modern cultivars have been selected by breeders for high input of nutrients, whereas landraces were grown in environments of low input (Pswarayi et al. 2008). Also, the genotype's response to high $\left[\mathrm{CO}_{2}\right]$ is likely related to age of the cultivar/landrace. One hypothesis is that as landraces were grown at times when the concentration of $\mathrm{CO}_{2}$ was lower than today and therefore, in high $\left[\mathrm{CO}_{2}\right]$ environments, they are unable to exploit the extra $\mathrm{CO}_{2}$. Contesting the validity of this hypothesis is the comparison of a total of 10 modern and previous wheat cultivars (Manderscheid and Weigel 1997; Ziska et al. 2004). These studies suggested that yield was more stimulated by high atmospheric $\left[\mathrm{CO}_{2}\right]$ in the old genotypes bred under pre-industrial levels of $\left[\mathrm{CO}_{2}\right]$, as the older cultivars responded to the higher $\left[\mathrm{CO}_{2}\right]$ by producing more tillers and ears. This is contrary to the yield pattern found in the new and old genotype analyzed in the present study. The observation that crop cultivars respond differently to climate change scenarios has been documented by others from studies with barley, oat and oilseed rape (Fangmeier et al. 2000; Chauhan et al. 2005; Johannessen et al. 2002, 2005; Clausen et al. 2011), and gives hope to that selection of specific cultivars with tolerance to abiotic stressors may help safeguarding the future primary production.

The potential for fast adaptation to abiotic stress in barley

In the future climate treatments, the G4-generation of both barley genotypes did not improve its production compared to the G0-generation; rather, G4 tended to have a lower reproductive output than G0. Especially at elevated $\left[\mathrm{CO}_{2}\right]$ the $\mathrm{G} 4$-generation responded worse than $\mathrm{G} 0$, and at elevated $\left[\mathrm{CO}_{2}\right]$ also the vegetative biomass was decreased. On the indicators of yield-seed dry weight, seed number and HI-significant effects were found by the ANOVA (Table 2), when generation was combined with higher temperature and elevated $\mathrm{CO}_{2}$. In a review of the evolutionary aspects of past, present and future atmospheric $\left[\mathrm{CO}_{2}\right]$ Leakey and Lau (2012) concluded that on a geological timescale, adaptations to low $\left[\mathrm{CO}_{2}\right]$ could be verified, but periods of high $\left[\mathrm{CO}_{2}\right]$ apparently did not drive major events in plant evolution. Also for the increases in $\left[\mathrm{CO}_{2}\right]$ in recent times (last 60 years) there is no clear evidence of plant evolution (Leakey and Lau 2012). This is in accordance with our results, and we hypothesize that the negative response to future climate changes found in the two barley genotypes analyzed, indicate that they neither possessed 
sufficient phenotypic plasticity nor the ability for fast genetic change necessary to counteract stress from elevated $\left[\mathrm{CO}_{2}\right]$ and temperature. On the other hand, as suggested from the ambient treatment, adaptation might take place under conditions mimicking today's environment. In their review Leakey and Lau (2012) suggested targeted breeding towards high yield under the elevated $\left[\mathrm{CO}_{2}\right]$ that we will experience in the future.

This inability of barley to respond positively to fast selection under elevated $\left[\mathrm{CO}_{2}\right]$ is contrary to the response pattern found in oilseed rape. In the only other study specifically addressing differences between crop generations in response to elevated $\left[\mathrm{CO}_{2}\right]$, Frenck et al. (2013) documented that selection had the potential to improve plant fitness including yield in oilseed rape. This diverging response in oilseed rape and barley to selection can possibly be ascribed to their different life history and different levels of genetic diversity: In contrast to the diploid inbreeding barley, oilseed rape is a partly outbreeding tetraploid; the alloploidy provides the species with an extra set of genes, and possibly also with higher general genetic diversity, which may lead to more phenotypic plasticity-19 and $47 \%$ polymorphic AFLP markers found in 'Anakin' and "Gammel Dansk", respectively is less than 60-68\% polymorphic markers found in the oilseed rape cultivars analyzed by Frenck et al. (2013). The higher phenotypic plasticity of oilseed rape is likely reflected in its "weedyness". Oilseed rape has several weedy characteristics that are not found in barley, e.g. abundant seed production, ability to cross- as well as selfpollinate, persistent seeds, seed production and seed germination in a wide variety of environments, etc. These are all characteristics that broaden the environmental range of oilseed rape, so that it can be found as a weed or ruderal plant in many places-simply providing oilseed rape with better adaptive capacity towards environmental change.

Barley is a crop adapted to the cooler climates, why negative effects from elevated temperature may be predicted, and as reported here adaptation to $+5{ }^{\circ} \mathrm{C}$ is apparently not possible over five generations in the two study-genotypes. Like barley, oilseed rape did not show adaptation to elevated temperature during the generational selection experiment (Frenck et al. 2013). The results from the present study indicate that selection pressures over five generations did not improve the production of barley, neither under elevated $\mathrm{CO}_{2}$, elevated temperature or their combination. In the ambient treatment, however, positive natural selection was apparently observed. As the response to the selection pressure had different directions in the different treatments, we may assume that the reaction-patterns recorded in the "elevated scenarios", were not just effects of small experimental population size, selfpollination and thus inbreeding over generations. Endogenous heterogeneity was present in the genomes of the two accessions at the start of the experiment, but the rate of gene flow between individuals within the population could have been a critical factor limiting rate of adaptation to climate change (Savolainen et al. 2004; Jump and Peñuelas 2005). Genetic drift is another factor that cannot totally be ruled out and may have affected the genetics of the experimental populations and caused the different directional responses to natural selection in the treatments.

Jump and Peñuelas (2005) stated that keeping all other factors constant, annual plants will adapt faster to a changing environment because of their short generation time. Based on a selection experiment using three generations of wild mustard under five stress regimes (high boron, high salt, low light, low nutrient or optimal conditions), Stanton et al. (2004) documented that selection in annual plants resulted in an evolutionary shift towards early flowering, a mechanism that could be described as stress avoidance. They also discussed that opportunity of selection varied based on origin of the crop cultivars, suggesting that artificial selection, inbreeding (most likely not the case in the present experiment-see above) and drift might influence adaptive responses to environmental stresses. Even though we used two accessions of barley of widely different age, breeding history and genetic diversity, we acknowledge that the plant material was limited. It cannot be ruled out that other barley cultivars can adapt quickly to climate stressors; therefore a larger array of genotypes should be screened. The experiment, however, may have its methodological merits showing, how a generational selection experiment can be conducted over at relatively short time frame. To follow the adaptation over many plant generations at lower selection pressures would possibly give a better reflection of the natural microevolution in barley, but such long time experiments are hardly feasible, and information is needed now to prepare for tomorrow. 
Acknowledgments This study was funded by Ris $\emptyset$ DTU, Aarhus University and NordForsk (the Nordic Council of Ministers). Thanks to colleges in the NordForsk network for "Sustainable primary production in a changing climate" for valuable discussions. The staff at Ris $\varnothing$ DTU is also thanked for their assistance.

\section{References}

Altenbach SB, Dupont FM, Kothari KM, Chan R, Johnson EL, Lieu D (2003) Temperature, water and fertilizer influence the timing of key events during grain development in a US spring wheat. J Cereal Sci 37:9-20. doi:10.1006/jcrs.2002. 0483

Amthor JS (2001) Effects of atmospheric $\mathrm{CO}_{2}$ concentration on wheat yield: review of results from experiments using various approaches to control $\mathrm{CO}_{2}$ concentration. Field Crop Res 73:1-34

Anderson JT, Willis JH, Mitchell-Olds T (2011) Evolutionary genetics of plant adaptation. Trends Genet 27:258-266

Araus JL, Slafer GA, Royo C, Serret MD (2008) Breeding for yield potential and stress adaptation in cereals. Crit Rev in Plant Sci 27:377-412

Barnabas B, Jager K, Feher A (2008) The effect of drought and heat stress on reproductive processes in cereals. Plant Cell Environ 31:11-38. doi:10.1111/j.1365-3040.2007.01727.x

Brantestam AK, von Bothmer R, Dayteg C, Rashal I, Tuvesson S, Weibull J (2007) Genetic diversity changes and relationships in spring barley (Hordeum vulgare L.) germplasm of Nordic and Baltic areas as shown by SSR markers. Genet Resour Crop Evol 54:749-758. doi:10.1007/s10722006-9159-4

Ceccarelli S, Grando S, Maatougui M, Michael M, Slash M, Haghparast R, Rahmanian M, Taheri A, Al-Yassin A, Benbelkacem A, Labdi M, Mimoun H, Nachit M (2010) Plant breeding and climate changes. J Agric Sci 148:627-637. doi:10.1017/S0021859610000651

Chauhan S, Khandelwal RS, Prabhu KV, Sinha SK, KhannaChopra R (2005) Evaluation of usefulness of daily mean temperature studies on impact of climate change. J Agron Crop Sci 191:88-94. doi:10.1111/j.1439-037X.2004.00122.x

Clausen SK, Frenck G, Linden LG, Mikkelsen TN, Lunde C, Jørgensen RB (2011) Effects of single and multifactor treatments with elevated temperature, $\mathrm{CO}_{2}$ and ozone on oilseed rape and barley. Eur J Agron 10:73-79. doi:10. 1111/j.1439-037X.2011.00478.x

Elke M, Kilianb J, Harterb K, Janssonc C, Wankeb D, Sundberga E (2011) Transcriptome analysis of high-temperature stress in developing barley caryopses: early stress responses and effects on storage compound biosynthesis. Mol Plant 4:97-115

Ellis RP, Forster BP, Robinson D, Handley LL, Gordon DC, Russell JR, Powell W (2000) Wild barley: a source of genes for crop improvement in 21st century. J Exp Bot 51:9-17. doi:10.1093/jexbot/51.342.9

Fangmeier A, Chrost B, Högy P, Krupinska K (2000) $\mathrm{CO}_{2}$ enrichment enhances flag leaf senescence in barley due to greater grain nitrogen sink capacity. Environ Exp Bot 44:151-164
FAO (2009) How to feed the world in 2050. http://www.fao.org/ fileadmin/templates/wsfs/docs/expert_paper/How_to_Feed_ the_World_in_2050.pdf

Frenck G, van Linden L, Mikkelsen TN, Brix H, Jørgensen RB (2011) Increased $\left[\mathrm{CO}_{2}\right]$ does not compensate for negative effects on yield caused by higher temperature and $\left[\mathrm{O}_{3}\right]$ in Brassica napus L. Eur J Agron 35:127-134. doi:10.1016/j. eja.2011.05.004

Frenck G, Linden L, Mikkelsen TN, Brix H, Jørgensen RB (2013). Response to multi-generational selection under elevated $\left[\mathrm{CO}_{2}\right]$ in two temperature regimes suggests enhanced carbon assimilation and increased reproductive output in Brassica napus L. Ecol Evol 3:1163-1172. doi:10.1002/ece 3.523

Hakala K, Jauhiainen L, Himanen SJ, Rötter R, Salo T, Kahiluoto H (2012) Sensitivity of barley varieties to weather in Finland. J Agric Sci 150:145-160. doi:10.1017/ S0021859611000694

Hatfield JL, Boote KJ, Kimball BA, Ziska LH, Izaurralde RC, Ort D, Thomson AM, Wolfe D (2011) Climate impacts on agriculture: implications for crop production. Agron J 103:351-370. doi:10.2134/agronj2010.0303

IPCC (2007) Climate change 2007: the physical science basis. In: Solomon S, Qin D, Manning M, Marquis M, Averyt K, Tignor MMB, Miller HL, Chen Z (eds) Contribution of working group I to the third assessment report of the intergovernmental panel on climate change. Cambridge University Press, Cambridge, pp 749-843

Jablonski LM, Wang XZ, Curtis PS (2002) Plant reproduction under elevated $\mathrm{CO}_{2}$ conditions: a meta-analysis of reports on 79 crop and wild species. New Phytol 156:9-26. doi:10. 1046/j.1469-8137.2002.00494.x

Jaggard KW, Qi A, Ober ES (2010) Possible changes to arable crop yields by 2050. Phil Trans R Soc B 365:2835-2851. doi:10.1098/rstb.2010.0153

Johannessen MM, Mikkelsen TN, Jørgensen RB (2002) $\mathrm{CO}_{2}$ exploitation and genetic diversity in winter cultivars of oilseed rape (Brassica napus); cultivars of tomorrow. Euphytica 128:75-86

Johannessen MM, Mikkelsen TN, Nersting LG, Gullord M, von Bothmer R, Jorgensen RB (2005) Effects of increased atmospheric $\mathrm{CO}_{2}$ on varieties of oat. Plant Breed 124:253-256. doi:10.1111/j.1439-0523.2005.01096.x

Jump AS, Peñuelas J (2005) Running to stand still: adaptation and the response of plants to rapid climate change. Ecol Lett 8:1010-1020. doi:10.1111/j.1461-0248.2005.00796.x

Kraakman ATW, Niks RE, Van den Berg PMMM, Stam P, Van Eeuwijk FA (2004) Linkage disequilibrium mapping of yield and yield stability in modern spring barley cultivars. Genetics 168:435-446. doi:10.1534/genetics.104.026831

Leakey ADB, Lau JA (2012) Evolutionary context for understanding and manipulating plant responses to past, present and future atmospheric $\left[\mathrm{CO}_{2}\right]$. Phil Trans R Soc B 367:613-629. doi:10.1098/rsth.2011.0248

Lobell DB, Field CB (2007) Global scale climate-crop yield relationships and the impacts of recent warming. Environ Res Lett 2:014002. doi:10.1088/1748-9326/2/1/014002

Long SP, Ainsworth EA, Leakey ADB, Nösberger J, Ort RD (2006a) Food for thought: lower-than-expected crop yield stimulation with rising $\mathrm{CO}_{2}$ concentrations. Science 312:1918-1921. doi:10.1126/science.1114722 
Long SP, Zhu XG, Naidu SL, Ort DR (2006b) Can improvement in photosynthesis increase crop yields? Plant Cell Environ 29:315-330. doi:10.1111/j.1365-3040.2005.01493.x

Luo Q, Bellotti W, Williams M, Wang E (2009) Adaptation to climate change of wheat growing in South Australia: analysis of management and breeding strategies. Agric Ecosyst Environ 129:261-267. doi:10.1016/j.agee.2008. 09.010

Makino A (2011) Photosynthesis, grain yield, and nitrogen utilization in rice and wheat. Plant Physiol 155:125-129. doi:10.1104/pp.110.165076

Manderscheid R, Weigel HJ (1997) Photosynthetic and growth responses of old and modern spring wheat cultivars to atmospheric $\mathrm{CO}_{2}$ enrichment. Agric Ecosyst Environ 64:65-73

Manderscheid R, Weigel J (2006) Responses of cereals and sugar beet in a crop rotation to free air carbon dioxide enrichment. Bibliotheca Fragm Agron 11:309-310

Martín-Olmedo P, Rees RM, Grace J (2002) The influence of plants grown under elevated $\mathrm{CO}_{2}$ and $\mathrm{N}$ fertilization on soil nitrogen dynamics. Glob Change Biol 8:643-657. doi:10. 1046/j.1365-2486.2002.00499.x

Nevo E, Fub Y-B, Pavliceka T, Khalifaa S, Tavasia M, Beilesa A (2012) Evolution of wild cereals during 28 years of global warming in Israel. Proc Natl Acad Sci USA 109:3412-3415. doi:10.1073/pnas.1121411109

Newton AC, Akar T, Baresel JP, Bebeli PJ, Bettencourt E, Bladenopoulos KV, Czembor JH, Fasoula DA, Katsiotis A, Koutis K, Koutsika-Sotiriou M, Kovacs G, Larsson H, Pinheiro de Carvalho MAA, Rubiales D, Russell J, Dos Santos TMM, Vaz Patto MC (2010) Cereal landraces for sustainable agriculture. A review. Agron Sustain Dev 30:237-269. doi:10.1051/agro/2009032

OECD-FAO Agricultural Outlook (2012) doi:10.1787/agr_ outlook-2012-en

Prasad PVV, Boote KJ, Allen LH, Thomas JMG (2002) Effects of elevated temperature and carbon dioxide on seed-set and yield of kidney bean (Phaseolus vulgaris L.). Glob Change Biol 8:710-721. doi:10.1046/j.1365-2486.2002.00508.x

Pswarayi A, van Eeuwijk FA, Ceccarelli S, Grando S, Comadran J, Russell JR, Pecchioni N, Tondelli A, Akar T, Al-Yassin A, Benbelkacem A, Ouabbou H, Thomas WTB, Romagosa I (2008) Changes in allele frequencies in landraces, old and modern barley cultivars of marker loci close to QTL for grain yield under high and low input conditions. Euphytica 163:435-447. doi:10.1007/s10681-008-9726-1
Savolainen O, Bokma F, Garcia-Gil R, Komulainen P, Repo T (2004) Genetic variation in cessation of growth and frost hardiness and consequences for adaptation of Pinus sylvestris to climatic changes. For Ecol Manag 197:79-89. doi:10.1016/j.foreco.2004.05.006

Scursoni JA, Satorre EH (2005) Barley (Hordeum vulgare) and wild oat (Avena fatua) competition is affected by crop and weed density. Weed Technol 19:790-795. doi:10.1614/ WT-03-065R.1

Semenov MA, Shewry PR (2011) Modeling predicts that heat stress, not drought, will increase vulnerability of wheat in Europe. Sci Rep 1 66. doi:10.1038/srep00066

Smil V (2005) Do we need higher farm yields during the first half of the 21st century? In: Sylvester-Bradley R, Wiseman J (eds) Yields of farmed species. Nottingham University Press, Nottingham, pp 1-14

Stanton ML, Thiede DA, Roy BA (2004) Consequences of intraspecific competition and environmental variation for selection in the mustard Sinapsis arvensis: contrasting ecological and evolutionary perspectives. Am Nat 164:736-752. URL: http://www.jstor.org/stable/10.1086/ 425331

Taub DR, Seemann JR, Coleman JS (2000) Growth in elevated $\mathrm{CO}_{2}$ protects photosynthesis against high-temperature damage. Plant Cell Environ 23:649-656. doi:10.1046/j. 1365-3040.2000.00574.x

Tubiello FN, Donatelli M, Rosenzweig C, Stockle CO (2000) Effects of climate change and elevated $\mathrm{CO}_{2}$ on cropping systems: model predictions at two Italian locations. Eur J Agron 13:179-189

United Nations (2010) World population prospects. The 2010 revision: http://esa.un.org/wpp/unpp/panel_population.htm

USDA (2011) Production, supply and distribution online: http:// www.fas.usda.gov/psdonline/psdHome.aspx

Warren JM, Norby RJ, Wullschleger SD (2011) Elevated $\mathrm{CO}_{2}$ enhances leaf senescence during extreme drought in a temperate forest. Tree Physiol 31:117-130. doi:10.1093/ treephys/tprO02

Ziska LH, Morris CF, Goins EW (2004) Quantitative and qualitative evaluation of selected wheat varieties released since 1903 to increasing atmospheric carbon dioxide: can yield sensitivity to carbon dioxide be a factor in wheat performance? Glob Change Biol 10:1810-1819. doi:10. 1111/j.1365-2486.2004.00840.x 